\title{
CAPACITY BUILDING THROUGH KNOWLEDGE ALLIANCES AND COLLABORATIVE CREATIVITY
}

\author{
Irena Dychawy Rosner \\ Malmö University, Sweden
}

\begin{abstract}
Across the social work and social pedagogy educational programmes in Sweden, the nature and process of curriculum designs require engagement with multiple stakeholders within a highly complex context. A number of studies have identified diverse models of academic collaborations derived from various theoretical positions and environmental influences. This article explores collaborative creativity embedded in Swedish national and international Erasmus networking. Research participants consisted of teaching staff, fieldworkers, experts and researchers. This study goes on to propose knowledge alliances as action models for capacity building in social pedagogy and social work professional practice. It is concluded that sharing information and perspectives on, for example, contextual aspects and theoretical viewpoints in which scholars and practitioners operate, provides inspiration for capacity building in social pedagogical educational settings. This article has been prepared within the framework of the project 'Social Professions for Youth Education in the Context of European Solidarity' (2019-1-PL 01-KA203-065091).

KEYWORDS: collaboration, creativity, social pedagogy, social work, health and society, higher education, IaH.
\end{abstract}

\begin{abstract}
Anotacija
Švedijoje vykdant socialinio darbo ir socialinès pedagogikos studijų programą, kuriant visa apimančią aplinką, svarbu bendradarbiauti su įvairiais partneriais. Atlikta nemažai tyrimų, kur ịvairiais teoriniais aspektais nagrinèti tokio bendradarbiavimo modeliai. Šiame straipsnyje analizuojamas kūrybinis bendradarbiavimas plètojant Švedijos nacionalinę ir tarptautinę Erasmus tinklaveiką. Tyrime dalyvavo dèstytojai, ekspertai, tyrèjai. Atskleista, kaip žiniomis pagrịstas veiklos modelis gali būti igyvendinamas socialinès pedagogikos ir socialinio darbo praktikoje ugdant gebejimus. Galima teigti, kad apsikeitimas informacija ir požiūriais skatina ugdytis gebejjimus, rengiant socialinès pedagogikos specialistus. Daroma išvada, kad dalijimasis informacija ir perspektyvomis, pvz., apie kontekstinius aspektus ir teorinius požiūrius, ịkvepia ugdytis gebėjimus socialinèje pedagoginèje švietimo aplinkoje. Straipsnis parengtas pagal projektą „Socialinės jaunimo ugdymo profesijos Europos solidarizacijos kontekste“" (2019-1-PL01-KA203-065091).

PAGRINDINIAI ŽODŽIAI: bendradarbiavimas, kūrybiškumas, socialinė pedagogika, socialinis darbas, sveikata ir visuomenè, aukštasis mokslas, IaH (internacionalizacija namuose).
\end{abstract}

DOI: http://dx.doi.org/10.15181/tbb.v84i1.2135

\section{Introduction}

The increasingly complex imperatives of the Bologna Process in higher education, together with an increasingly globalised and interconnected world, calls for a creative reinterpretation of the positioning and development of educational programmes (EACEA, 2018). According to the Organisation for Economic Coopera- 
tion and Development (OECD, 2014), there are more than 4.5 million international students registered at universities worldwide. Consequently, higher education sites have become unique spaces for social interaction and knowledge exchange between countries, students and academic staff, and in the increasingly complex imperatives. Developing diverse working connections between educational programmes, staff and student exchanges demonstrates an important role for transition of experience, evolvement of teachers' roles, and socialising of students, as well as for a sense of international group solidarity (Dychawy Rosner, Christensen, 2016; Trygged, Eriksson, 2012). In the wider literature, the nature of social work and the social pedagogy applied thereto have begun to receive more attention. This is in terms of international understandings of the function and practice of both social pedagogy and social work. Many scholars have developed diverse academic networks and collaborative regimes, in an attempt to raise awareness of the developmental nature of contemporary practice, research, scholars' lived experiences and mutual consultations (NERA, 2017; NSN, 2019).

Social pedagogy and social work are considered as related concepts and areas interconnected with community work. In this paper, the terms social pedagogy, social work and social pedagogical social work are used interchangeably. The terms refer to pedagogical approaches within social work professional practice. Researchers have identified key social pedagogical features, such as enduring relationships, holistic views in promoting well-being, and pedagogic-based support schemes comprising both universalistic and particularistic approaches to practice (Hallstedt, Högström, 2005; Cameron, 2004; Eriksson, 2014; Kyriacou, 2009). Some maintain that social pedagogy is a subject connected to other social and educational science studies rather than an area in its own right (Janer, Úcar, 2019). Social pedagogy has difficulties staying independent of other subjects and professional fields such as, for example, social work (Högström, 2018). In Sweden, social pedagogy is mostly included within social work education, but specific social pedagogy programmes also exist, for instance in Högskolan Väst.

This study explores collaborative creativity within the spectrum of national and international collaborative knowledge networks in social pedagogy and social work education not addressed in the wider literature. Collaborative creativity in social pedagogical network perspectives and knowledge alliances, in this paper, relate to events involving dialogues, sharing experiences, exchanging narratives and other forms of communication, which express the social and cultural location of the participating scholars. In drawing attention to these issues, my intention is not to provide a comprehensive model of creativity, but to contribute to and broaden understanding, exemplifying challenges and possibilities in relation to knowledge alliances in social work professions. 
The aim here is to depict some issues of central importance in how learning, teaching and knowledge alliances for curriculum development can be stimulated by local and international disciplinary collaboration, exchange and networking. The study illustrates and reflects on examples of collaborative creativity experienced from two perspectives; creativity embedded in relational spaces, and creativity embedded in collaborative networking as platforms for curricular development.

\section{Creativity embedded in relational spaces}

Perspectives on creativity as embedded in relational spaces can be understood through activities organised within the Swedish National Social Pedagogy Network (NSN). This academic, professional and vocational network attempts to generate wider concern and inter-professional cohesion regarding the importance of various social pedagogy practices and theoretical approaches (Högskolan Väst, 2018). This kind of networking is interesting, as it connects dialogue, communicative inter-subjectivity and relations that may help bring out the potential of more informal ways of perceiving the current state of affairs. The discussions and disciplinary exchange in Sweden include social pedagogy within social work as an area of expertise, academic subject and professional action (Eriksson, Markstöm, 2000).

Creative alliances formed through actions and relationships with others, sharing ideas, and attaining information are, for example, achieved through taking part at national exchange levels. The network organises conferences, workshops and scholars' update exchange meetings. NSN network alliances point towards the socio-pedagogical social dimensions in social pedagogy and the social work field work by using ideas from dialogic systems of meanings, and focus on the significance of the notion of communities of practice (Wenger, 2000). This corresponds with contextual sensitivity and contemporary social pedagogy practice and theory (Cameron, 2004; Cedersund, Eriksson, Ringby Jansson, Svensson, 2019). The creative atmosphere within these alliances engages scholarship from many Swedish universities and educational programmes.

For instance, the two-day open space conference programme held in Västervik in November 2018 (Högskolan Väst, 2018) was subject to actual educational information and presentations of ongoing projects. This went along with discussions about creativity and interactions within physical treatment rooms and professional social pedagogy work when supporting the life choices of young peoples, as well as future activity plans for clients. Sharing experiences through meetings provided new spaces for learning from one another. For example, during the conference in Västervik, Dychawy Rosner and Högström (2018) received feedback, validity 
measure and an invaluable opportunity to discuss a previously developed challenged-based learning (CBL) checklist. The CBL methodology was initiated at the BA social work educational programme in Malmö.

The latest research was furthermore exemplified by the presentation of an article analysing the theoretical roots of social pedagogy in the course of reviewing what references Swedish researchers use in their text production regarding social pedagogy publications from the years 1991 to 2018 (Högström, 2018). The general discussions on shared knowledge during the Västervik conference highlighted the fact that while sociological perspectives influence the theoretical aspects, the practice implementations focus on pedagogical and intersubjective dimensions of social pedagogy social work.

The practice of social pedagogy within social work is fundamentally linked to interactional relations between professional workers and their clients. Therefore, the social professions develop unique profiles. Hämäläinen (2012), studying semantic concepts within social pedagogy, outlined this subject as embracing perspectives of conceptions of the pedagogy, as well as being an idea and attribute of the social. These perspectives are directed towards actions supporting social care and welfare facilities, and inclusive models of social pedagogy practice towards schemes of equality and membership in mainstream society. Much Nordic thinking and debate on social pedagogy relies on previous outcomes of the debate in Germany (Lorenz, 2008). Furthermore, the contemporary German discourse (Grunwals, Thiersch, 2009) shapes social pedagogy as a dimension of the lifeworld orientation of the client's everyday life and professional actions in the public sector of social service provision in the field of social work and social care. In addition, this dimension of practice, differentiates social pedagogy within social welfare practices as operating partly as procedural measures and partly as social pedagogic (e.g. intersubjective) dimensions of practice (Morgan, 2013). Not only is academic knowledge based on empirical scientific evidence essential for forming key competence with regard to clinical knowledge, but also knowledge based on the individual experiences of those benefiting from the interventions (Grunwals, Thiersch, 2009; Kyriacou, 2009).

\section{Creativity embedded in collaborative networking}

The notion of creativity has attracted attention as a complex and dynamic system from the point of view of personal ability and as a product of creative response. In theoretical approaches, the concept of creativity in theoretical approaches is subjected to the process of interactions specified on the level of the direct environment embedded in a domain of culture within society (Bernstein, 1996; Miller, 
2004; Osborne, 1996; Vygotsky, 1978). Creativity shaped through the exchange of narratives and reflexivity between teachers, researchers and practitioners denotes here that the created knowledge alliances construct a particular reality, in which social pedagogy and social work situate capacity building itself (Jenlink, 2004; Wenger, 2000; Whittington, 2003). Collaborative creativity may be viewed as an active form of working together, and as a search for solutions that go beyond the individual partner perspective. It is an active process of partnership in action, which enables all participants to find beneficial responses and solutions.

Although academic partnership coalitions, networking and international practices in higher education are growing in popularity, relatively little is known about them, since capacity building through networking practices has garnered little attention in the literature. Burgess (2004) suggests that creativity in curriculum design involves making sense of multiple factors, and introducing innovative approaches to guiding students to manage complex and unpredictable situations. This creative practice may include openness to the outside world, the exchange of ideas across borders, and supporting students' reflective skills through convergent and divergent thinking strategies (Trygged, 2010; Varus, Bartlett, 2012). In relation to curriculum development, these may be seen as perspectives of combining knowledge, values and skills, implicitly and explicitly embedded in diverse academic social work institutions and networks alliances (Cook-Sather, 2006; Dychawy Rosner, 2018; Habermas, 1971; Trygged, 2010).

Morgan (1998) describes collaboration as a process-oriented living system. Higher education (HE) institutions resemble collaborative internationalisation, as the exchange of views and ideas is subjected to international influences. According to Duffield, Olson and Kerzman (2013), HE institutions, as part of a larger state system, are designed for individual missions, and not for collaboration with each other. Several attempts have been made to redesign HE for collaboration, for example, by introducing requirements for partnership in order to receive funding, such as through European Union (EU) programmes for education. Thus, understanding collaborations within social pedagogy and social work knowledge alliances can be shaped as a process involving decontextualising assumptions typically taken for granted (Burgess, 2004; Bernstein, 1996; Dychawy Rosner, 2018; Hallstedt, Högström, 2005). While some have seen collaborative knowledge alliances as unique relations, social work and social pedagogy practice show that the created networking interactional spaces situate the discipline occurring in social structures and political contexts both internationally and locally (NERA, 2017; NSN, 2019). 
Irena Dychawy Rosner

\section{Capacity building and developing strategic partnerships within Erasmus relationships}

An example of the creativity process in capacity building may be illustrated by developmental work conducted in 2016 and 2017 by a group of academic colleagues connected to Department of Social Work of the Faculty of Health and Society at Malmö University. The collaborating institutions came together in Malmö through the scholarly European Erasmus Move On collaboration, as partner countries to deepen and develop their earlier scholarship exchange. This developmental process included study visits to each other's universities, arranging working meeting sessions, sharing institutional documentation and educational experiences, as well as informal socialisations. At the initial level, the participating academic staff were represented by Malmö University, Warsaw University and Klaipèda University. The idea for more collaborative networking and research came from a study undertaken as part of a pedagogical development project relating to challengebased learning that emphasised the conceptions of learning and pedagogic strategies in social work education, while adding social pedagogy meaning in students' fieldwork tasks (Dychawy Rosner, Högström, 2018). The project's international exchange and cooperation relates to Habermas' concept of communicative action, and the idea that knowledge is basically a developmental construction inspired by the interests of users (Habermas, 1971; Wenger, 2000) and scholastic knowledge development (Burgess, 2004; Dychawy Rosner, Christensen, 2016; Trygged, Eriksson, 2012; Smith, Cheung, 2015). A key concern for the development work here was the possibility of forming a culture of collaboration in which to create a joint action idea, permitting the mobilisation of the educational competences inherent in partner organisations. An essential condition at this initial stage was the foundation of a creative space, and the willingness to share experiences gained through each partner's scholarly work.

The next stage, developing strategic partnerships, began with a three-day network meeting at the University of Warsaw in September 2018. Six universities participated in this teamwork meeting, representing social work and social pedagogy educational institutions in Poland (University of Warsaw, WU), Sweden (Malmö University, MAU), Lithuania (Klaipėda University, KLU), Belgium (Hasselt University, UCLL), Germany (Evangelische Hochschule Darmstad, EFHD) and Latvia (Cristian Academia, LCA). This means that the group of participants represented Central, Scandinavian and East European educational institutions. In contemporary professional frameworks, East European social workers are involved in social support and massive reconstruction projects after the fall of Communism (Lorenz, 2008). The participating academic staff ( $\mathrm{n}=14$; working as tea- 
chers, programme managers, department directors, pedagogical coordinators and researchers) continued to put the networking project in concrete form, by studying and discussing the parameters for scholarship funding, as stated by the European Union Erasmus+ programme (EACEA, 2018). The focus of these discussions was on strategic needs and required developments according to the educational contexts of the participating universities. This effort generated representative themes recognised by all participants, such as a desire for aligned development, and thus important considerations regarding the higher education programmes serving social pedagogy and social work professionals.

\section{Curricular links for desired development}

There was varying interest connected to the existence of differing realities of social pedagogy in applied practice, educational regulations and uniformity, the university's academic cultures, and administrative institutional routines. Nevertheless, the participating faculties for social professions operate mostly in the local domain of the professional field. The meeting dialogues and the participants' scrutiny of existing educational and disciplinary regimes exhibited new meanings and generated new points of view. The conceptual frameworks were not seen here as merely models, but also as a formation embodying roles (students', teachers'), actions (lecturing, learning, disseminating), interactions (communicating, experiencing, etc), and also educational contexts. Within this construct, reasons were found for why educational programmes work the way they do. It was helpful to share diverse ways of conceptualising educational curricula, theoretical traditions and educational processes taking place in hierarchically organised settings. According to influences from the EU, each country has been adapting their social work education system to meet the standards of the Bologna Process, mainly inspired by the university system that supports the transfer of professional academic knowledge (European Commission, 2007).

While comparing each programme, some important institutional differences were unearthed when looking for recognition and common importance of social problems and educational demands. The generated themes are presented in Table 1, which is a summary of the reflective discussions associated with EU themes that were perceived as important or needed for collaborative practice, and international exchange opportunities to the participant institutions' educational programmes for teachers and students. The comparison was not based on normative models of social pedagogy or social work field frameworks, but on the participants' experiences and perceived developmental needs. The themes reflected the EU's endorsement of collaborative educational projects as key elements in the work on the social role of social pedagogy workers for European Values in the Globalised 
World (Jones, Radulescu, 2005; Kezar, 2005; Trygged, 2012; OECD, 2018). Discussions, reflections and thoughtful dialogues lead each university to process the eight EU items and focus on desired academic developments regarding the social pedagogy within the social work field of education and practice. The content of each emerged theme, as determined by participants during the Warsaw meeting, is presented in Table 1.

Table 1. Themes of desired areas of collaborative academic development in social pedagogy and social work education

\begin{tabular}{|l|l|}
\hline $\begin{array}{l}\text { Themes of EU endorsements of } \\
\text { HE collaborative projects }\end{array}$ & $\begin{array}{l}\text { Development potential desired } \\
\text { by each HE institution }\end{array}$ \\
\hline $\begin{array}{l}\text { 1. Strengthening cooperation and networ- } \\
\text { king between organisations }\end{array}$ & \\
\hline $\begin{array}{l}\text { 2. Promoting development, testing and im- } \\
\text { plementation of innovative practices }\end{array}$ & EHD, UCLL, WU, MAU, LCA, \\
\hline $\begin{array}{l}\text { 3. Promoting recognition and validation of } \\
\text { knowledge, skills, and competences }\end{array}$ & EHD, UCLL, WU, UCLL \\
\hline $\begin{array}{l}\text { 4. Promoting cooperation between regio- } \\
\text { nal authorities to develop new systems for } \\
\text { education, training and youth }\end{array}$ & \\
\hline $\begin{array}{l}\text { 5. Supporting learners with disabilities and } \\
\text { special needs and easing their transition to } \\
\text { the labour market }\end{array}$ & \\
\hline $\begin{array}{l}\text { 6. Supporting education and training pro- } \\
\text { fessionals to promote equity, diversity and } \\
\text { inclusion in learning }\end{array}$ & UCLL, WU, MAU \\
\hline $\begin{array}{l}\text { 7. Promoting integration of newly arrived } \\
\text { migrants and raising awareness about the } \\
\text { refugee crisis in Europe }\end{array}$ & MAU \\
\hline $\begin{array}{l}\text { 8. Promoting entrepreneurships and active } \\
\text { citizenship among young people }\end{array}$ & KLU, LCA \\
\hline
\end{tabular}

As is shown in Table 1, some items' dimensions regarding EU endorsement for collaborative projects were shown to be more silent than others (see Themes 1, 4, and 5). The evident impression was perceived in the field of, for example, collaboration (see Theme 1; strengthening cooperation and networking between organisations). This area provides a silent representative coverage or sampling of generic dimensions, not found to be of interest, when at the same time, the topic of all the discussions centred on how to collaborate and help each other develop existing social pedagogy knowledge by taking a constructivist position as active creators of this knowledge area (Miller, 2004). The ability to creatively collaborate in any joint educational space means extending capacity, taking risks within these spa- 
ces, and inviting constructivist critical and reflective engagements (Cook-Sather, 2006). Other dimensions, such as promoting the integration of newly arrived migrants and raising awareness about the refugee crisis in Europe (Theme, 7), were recognised as very important for developing scholarly programmes by the Swedish faculty, but were seen as less important by the others. This may indicate the occurrence, influence and importance of the socio-political environment in which social pedagogy and educational institutions act, and issues related to migration, immigrant services and the refugee crisis in Europe. There is a need to understand the big picture of capacity building in relation to the problem of welfare delivery and immigrant integration among social workers in Sweden (Dychawy Rosner, 2016; Eliassi, 2017). Promoting cooperation between regional authorities and supporting learners with disabilities and special needs (Theme 4), was considered appropriate for development most in connection to each faculty's local context, and less appropriate for the cross-national European arena.

In contrast, the main preference requesting developmental collaboration found to be very important was the second theme, requesting areas for promoting development, testing and implementation of innovative practices, selected by five of six participating universities (Theme 2). Four participating university departments ranked promoting recognition and the validation of knowledge, skills and competences (Theme 3) as important. Similarly, promoting cooperation between regional authorities to develop a new system for education, training and youth (Theme 4), as well as supporting learners with disabilities and special needs, and easing their transition to the labour market (Theme 5), was discussed as very important, but considered not to be adaptive to coordinate with time constraints and the bureaucracy of national and institutional regulations within the participating universities. (Theme 6) attained discussion and interests, but was considered to be too specific for local universities and communities of practice (Wenger, 2000), and after further consideration, it was decided that it could maybe prove difficult to collaborate on generalised solutions regarding this content.

The ongoing creative dialogues, and sharing of perspectives and considerations, revealed existing academic, institutional and field realities. It was likewise shown that it may also prove to be difficult to adopt socially critical approaches to your own curriculum designs. This role used to be played by national assessments of educational authorities. However, the developed items helped the group reorient their awareness about taken-for-granted assumptions that characterise differing institutional contexts, and correspondingly helped cultivate notions of occurring logics that guide teaching practices. Although this construction and reconstruction can be undertaken on an individual level, it can also be a pragmatic help for know- 
Irena Dychawy Rosner

ledge development itself, as well as a systematic process of formal education in a specific socio-cultural context.

\section{Discussion}

The illustrated examples of social pedagogical knowledge alliances and collaborative approaches in social work are much more than the simple application of professional exchange. Rather, they free up creatively developed ideas by creating spaces of dialogical and transformational knowing. This phenomenon allows individuals to articulate their ideas, aspirations and experiences, to recognise their relationships with those outside their local space. Otherwise stated, they encourage creatively developed ideas through a constructivist basis, which takes the individual, the position and structural factors within the discipline into account. Sharing individual experience and clinical knowledge within a disciplinary group of social pedagogy professionals, and disseminating ongoing research projects, as well as sharing new clinical practices, including scholars and practitioners (NSN, 2019), deepens the understanding of contemporary issues in social pedagogy. Although social pedagogical theorists differ in their exact definition of the subject, there are some fundamental approaches, such as paying attention to both the universal and the particular at the same time, and society's aim of social integration, which are integral aspects of the welfare society (Eriksson, 2014; Hallstedt, Högström, 2005; Hämeläinen, 2012; Trygged, 2010).

In spite of the differences in global and local orientation, and to avoid getting stuck on any particularities, the members of the Erasmus strategic partnership widened their discussions. They recognise and broaden values and knowledge based on general beliefs relating to social protection, equal citizenship rights and welfare opportunities, all of which were seen as issues central to socio-pedagogical social work practice (Eriksson, 2014; Jones, Radulescu, 2005; Trygged, 2010; OECD, 2018). There is a need for a practitioners' mission for social integration, and for educators to understand the global community, even though their work is done locally (Dychawy Rosner, Christensen, 2016; Trygged, 2010).

It is suggested that the professional workers' personal experiences and overall situation are important dimensions of choice embedded in the formalised practice frameworks. From this perspective, this study may illustrate some limitations when it comes to the understanding of complexities and ongoing changes within social practices (Wenger, 1997). It concentrates mainly on the exchange of micro-knowledge between academic teaching staff, and creativity embedded in the process of mutual discursive interactions and relational spaces. Educational programmes, as part of public administrations, reflect and contribute to a broader so- 
cial context, and therefore cannot be understood or developed in isolation from the experiences of academic staff (Duffield, Olson, Kerzman, 2013; Witkin, 2014). Whether through reasoning or accurate mapping of different scholars' practices, the existing experts' knowledge is the possession of individual minds (Bernstein, 1996; Burgess, 2004; Osborne, 1996). This perspective has to be linked to other potential factors, such as participating staff's individual expertise, interests and educational ideologies, as well as other factors which are often considered as professional challenges in the social pedagogical field of practice.

A methodological problem has been pointed out by Cook-Sather (2006), who claims that qualitatively intuitive approaches in teachers' research tend to overemphasise subjective experiences. Creativity in capacity building and knowledge alliances is, however, likely to be constrained by a variety of factors. It can be impacted by resource shortages and time constraints, or by contextual forces such as ideological or vocational influences, or even the bureaucracy of institutional procedures. Although there are some limitations, the creativity from collaborative networking here suggests benefits such as increased cross-border awareness, professionalism and culturally informed models that embrace global and local fields of practice (Cook-Sather, 2006). These influences reshape the role of educational practices related to the promotion of students' creativity which goes beyond a critique of beliefs and assumptions, to problematising, questioning and imagining how things could be different (Dychawy Rosner, 2018; Osborne, 1996; Witkin, 2014).

\section{Concluding remarks}

This study regards the collaborative venture creating national and international network spaces as beneficial. The participating academic institutions gained additional insights, and learned from each other. This led to the portrayal of education as a process which constructs various representations in relation to the epistemological and ontological reality as the social and human construction of knowledge and creative learning communities (Duffield, Olson, Kerzman, 2013; Witkin, 2014).

At the present time, the growing need for social pedagogy and similar social work support arrangements for vulnerable populations (such as the need to support the social integration and participation of young people with diverse vulnerable societal positions) is challenging the welfare system. The three years of the above-mentioned intensive national and international curricular exchange, the development of relational spaces, creative networking and searching for innovative solutions, resulted in a collaborative application for the EU Erasmus + Programme foundling call for 2019, entitled 'Cooperation for Innovation and the Exchange 
of Good Practices' (European Commission, 2019). Five institutions currently in partnership, the University of Bialystok's Faculty of Pedagogy and Psychology (PL), Malmö University's Faculty of Health and Society (SE), Klaipėda's Faculty of Health Sciences (LT), the Lithuania and Latvian Christian Academy (LV), and Warsaw University's Institute of Social Prevention and Resocialisation (PL), are collaboratively conducting a developmental project entitled 'Social Professions for Supporting Youth in a European Solidarity Context' (Erasmus + KA 203, 2019).

The common philosophy is to offer the individual receiving help as much control as possible over the way in which that help is delivered. Consequently, creativity embodied within collaborative networking and relational spaces may be a precondition for generating a deeper disciplinary understanding and locate broader-based professional capabilities. Shared platforms for curricular links, and transnational reflectivity and exchange, may foster critical approaches to social pedagogy and social work theories, applied models, and concepts of practice. Future research should pay more attention to knowledge alliances as creative actions for capacity building in curriculum development, with regard to understanding educational and disciplinary knowledge development issues in response to the social issues and problems of society.

\section{References}

Bernstein, B. (1996). Pedagogy, symbolic control and identity. Theory, research critique. Langham, Md: Rovman \& Littlefield Publishers.

Burgess, H. (2004). Redesigning the curriculum for social work education: Complexity, conformity, chaos, creativity, collaboration? Social Work Education, Vol. 23(2), p. 163-183.

Cameron, C. (2004). Social pedagogy and care. Danish and German practice in young people's residential care. Journal of Social Work, Vol. 4 (2), p. 133-151.

Cedersund, E., Eriksson, L., Ringby Jansson, B., \& Svensson, L. A. (2019). Social pedagogical practices in Swedich welfare contexts. International Journal of Social Pedagogy, Vol. 7 (1), p. 7. DOI: https://doi. org/10.14324/111.444.ijsp.2019.v7.1.007.

Cook-Sather, A. (2006). Education is a translation. A metaphor for change in learning and teaching. Philadelphia: PENN, University of Pennsylvania Press.

Duffield, S., Olson, A., \& Kerzman, R. (2013). Crossing borders, breaking boundaries: Collaboration among higher education institutions. Innovations in Higher Education, Vol. 38, p. 237-250.

Dychawy Rosner, I. (2016). Challenges of migration for social pedagogy in a Swedish context. Papers on Social Pedagogy, Vol. 1(4), p. 6-16. Available on line: https://pedagogikaspoleczna.uw.edu.pl/resources/html/cms/ MAINPAGE

Dychawy Rosner, I., \& Christensen, J. (2016). Globalisation brought into the classroom - Reflections from the local context in social work and nursing education. Tiltai: Bridges in Social Sciences, Vol. 74(2), p. 21-32. Available on line http://journals.ku.lt/index.php/tiltai/article/view/1364

Dychawy Rosner, I., \& Högström, M. (2018). A proposal for inquiry of network and challenge-based learning in social work education. Tiltai: Bridges in Social Sciences, Vol. 2, p. 43-54. DOI: http://dx.doi.org/10.15181/ tbb.v79i2.1776

Dychawy Rosner, I. (2018). Editor's notes: Socio-pedagogical knowledge expertise across the social care sectors in Northern Europe. Papers of Social Pedagogy, Vol. 1(8), p. 5-13. DOI: 10.5604/01.3001.0011.5847.

EACEA. (2018). European Commission Erasmus programme. Available on line: www.eurodesk.eu 


\section{CAPACITY BUILDING THROUGH KNOWLEDGE ALLIANCE...}

Eliassi, B. (2017). Conceptions of immigrant integration and racism among social workers in Sweden. Journal of Progressive Human Services, Vol. 28 (1), p. 6-35.

Erasmus + KA203. (2019). Strategic Partnerships for Higher Education. Social Professions for Supporting Youth in a European Solidarity Context. Retrieved July 23, 2020. Available on line: http://young.uwb.edu.pl/

Eriksson, L. (2014). The understanding of social pedagogy from northern European perspectives. Journal of Social Work, Vol. 14(2), p. 165-182.

Eriksson, L., \& Markström A. M. (2000). Den svårfångade socialpedagogiken [The elusive social pedagogy]. Lund: Studentlitteratur.

European Commission. (2007). Focus on the structure of higher education in Europe 2006/07: National trends in the Bologna Process. Retrieved April 23, 2019 from https://www.sel-gipes.com/uploads/1/2/3/3/12332890/2007 eurydice_-_focus_on_the_structure_of_higer_education_in_europe_2006-07_-_national_trends_in_th_ bologna_process.pdf

European Commission. (2019). EACEA, Erasmus +. KA2. Cooperation for innovation and the exchange of good practices. Bryssel. Available on line: https://eacea.ec.europa.eu/erasmus-plus/actions/cooperation-forinnovation-and-exchange-good-practices_en

Grunwals, K., \& Thierch, H. (2009). The concept of the lifeworld orientation for social work and social care. Journal of Social Work Practice, Vol. 23 (2), p. 131-146.

Habermas, J. (1971). Knowledge and human interest. Boston: Beacon Press.

Hallstedt, P., \& Högström, M. (2005). The recontextualisation of social pedagogy. A study of the curricula in the Netherlands, Norway and Ireland. Malmö Studies in Educational Sciences, No. 21. Malmö University. ISSN 1651-4513.

Högskolan Väst. (2018). Nationellt socialpedagogiskt nätverk. Campus Västervik. (In Swedish) accessed May, 08 2019. Available on line: https://www.hv.se/samverka-med-oss/sambarbeten-och-natverk/nationelltsocialpedagogiskt-natverk/

Högström, M. (2018). What is the Swedish interpretation of social pedagogy. A literature review. Papers of Social Pedagogy, Vol. 1(8), p. 51-65. DOI: 10.5604/01.3001.5650.

Janer, A., \& Úcar, X. (2019). An international comparison: Social pedagogy training. Journal of Social Work, Vol. 19(2), p. 253-275.

Jenlink, P. M. (2004). Education, social creativity, and the evolution of society. World Futures, Vol. 60, p. 225240.

Jones, D. N., \& Radulescu, A. (2005). Regional perspectives from Europe. Is there a European social model? Building and promoting social work in Europe. International Social Work, Vol. 49, p. 412-418.

Kezar, A. (2005). Redesigning for collaboration within higher education institutions: An exploration into the developmental process. Research within Higher Education, Vol. 46, p. 831-860. DOI:101007s111126-004-6227-5.

Kyriacou, C. (2009). The five dimensions of social pedagogy within schools. Pastoral Care in Education, Vol. 27 (2), p. 101-108.

Lorenz, W. (2008). Towards a model of social work. Australian Social Work, Vol. 61(1), p. 7-24.

Miller, R. (2004). Educational alternatives. A map of the territory. Paths of Learning, Vol. 20, p. 20-27.

Morgan, S. T. (2013). Social pedagogy within key worker practice: Community situated support for marginalised youth. International Journal of Social Pedagogy, Vol. 2 (1), p. 17-32. Available on line: http://www. internationaljournalofsocialpedagogy.com

NERA (2017). Nordic Educational Research Association. Available on line: https://neranetwork23.wordpress. $\mathrm{com} /$

NSN (2019). Nationellt socialpedagogiskt nätverk. Swedish National Social Pedagogy Network Available at: https://www.hv.se/samverka-med-oss/sambarbeten-och-natverk/fler-samarbeten/nationellt-socialpedago giskt-natverk/

OECD. (2018). Education at a glance 2014: OECD indicators. Available on line http://www.cnedu.pt/content/ noticias/internacional/Education_at_a_glance_2018.pdf

Osborne, J. F. (1996). Beyond constructivism. Science Education, Vol. 80(1), p. 53-82.

Ronnby, A. (1987). Socialarbetets förklaringsmodeller. The social work's explanatory models. 2nd ed. Malmö: Liber Förlag.

Trygged, S. (2010). Balancing the global and the local: Some normative reflections on international social work. International Social Work, Vol. 53(5), p. 644-655.

Trygged, S., Eriksson, B. (2012). How do students perceive the international dimension in social work education? 
Irena Dychawy Rosner

An enquiry among Swedish and German students. Journal of Social Work Education, Vol. 48(4), p. 655-667.

Vygotsky, L. (1997). Mind in society. Development of higher psychological process. Cambridge, MA: Harvard University Press.

Wenger, E. (2000). Communities of practice and social learning systems. Organisation, Vol. 7(2), p. 225-246.

Whittington, C. (2003). Collaboration and partnership in context. In J. Weinstein., C. Whittington, C. \& T. Leiba. Collaboration in social work practice. London: Jessica Kingsley Publishers, p. 13-38.

Witkin, S. L. (2014). Change and deeper change: Transforming social work education. Journal of Social Work Education, Vol. 50, p. 517-598.

Irena Dychawy Rosner - associate professor, doctor of Medical sciences, Department of Social Work, Faculty of Health and Society, Malmö University.

E-mail: irena.dychawy.rosner@mau.se 